\title{
An Empirical Analysis of Loans Pricing of Commercial Banks for SMEs Bases on RAROC Model
}

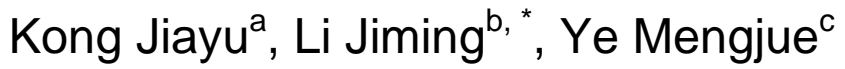 \\ Business School, Zhejiang University City College, Hangzhou, 310015, China \\ aemail: 1195144699@qq.com, ${ }^{\text {bemail: lijm@zucc.edu.cn, }{ }^{c} e m a i l: 11 x j o e @ s i n a . c n, ~}{ }^{*}$ corresponding \\ author
}

Keywords: RAROC Model, SMEs, Commercial Banks, Loan Pricing

\begin{abstract}
Recently more and more commercial banks are willing to provide loans to SMEs under the guidance of the government, however, how to provide reasonable loan pricing for SMEs becomes an urgent and core problem faced by these banks. Loan pricing will be affected by many factors, and is also a more complex systemic issue for commercial banks. Based on the loan pricing model of RAROC model, this paper empirically analyzes the factors such as operating cost, economic capital and expected losses by using the panel data of thirteen listed SMEs of Zhejiang province. The results shows that the loan rates adjusted by the risk based on the RAROC model are higher than the actual loan rates, and the low loans pricing leads to be not enough conducive to the bank's compensation and risk aversion. The conclusion indicates that the risk-adjusted loans pricing can provide reasonable compensation on the risk and improve the efficiency of the loan in the end.
\end{abstract}

\section{Introduction}

For small and medium enterprises (SMEs), as the severe information asymmetries and potential discriminations exist, commercial banks provide with higher rates above benchmark interest rate in the general business. Nowadays SMEs' loans pricing not only plays an important role in the total loan activities, but also is an essential part and a necessarily guarantee to achieve the loan origination and profit target. Setting the loan price tends to be affected by different endogenous and exogenous variables, which involve in many parts of modern commercial banks' operation and management. And it becomes a more and more complicated and systematic task for banks. As Chinese market-oriented reforms of interest rates carried forward and deeper, commercial banks gain more and more liberty of pricing enterprises' loan, and loans pricing begins to become the primary core of the commercial banks' credit operation and management. However, the framework of loan pricing basing on capital cost, loan risk and so on is just a first attempt and still has long way to explore.

With the development and exertion of loan pricing technology, commercial banks try to operate, manage, control risk based on credit, and pursue a balance between the risk and return, as well as chase risk-adjusted return which is regarded as the core of the future development direction. On the other hand, the regional discrepancies of the loan resources allocation results of the different operating levels of commercial banks, different economic and market surroundings. And those discrepancies also exist when come to different industries and enterprises in various operating levels. So, the loan pricing is likely to be more flexible, diverse and rational. Nowadays, banks in our country gradually take risk into account in loan pricing using differential pricing, while the benchmark interest rate offered by People's Bank of China plus or minus method prices is still the choices of majority, which means when facing enterprises in different hazard levels there are merely sight differentiations between loan prices.

Recently, constitutions in financial market generally adopt the RAROC risky management technology to set the loan price, which comprehensively takes return and risk into consideration. However, lacking the fundamental credit risk data and professionals internally results in the problems emerge in the practices of international advanced risk management and credit rating theory in our country. Those problems hinder improving the pricing level. Besides, there are 
limitations in RAROC model, such as depending on the historical data in banking business, ignoring the fierce competitions in loan market, neglecting the dynamic and closely correlation between the risk and market circumstances, escaping from the external marketing environment as well.

\section{Literature Review}

Some scholars study loans pricing from credit risk management and economic capital allocation using RAROC model. Corvoisier and Reint Gropp (2002) indicated that not only deposit rate and operating cost but also the quantity of bank plays a crucial role in determining loan rate. With other conditions unchanged, the higher market concentration degree, the higher loan rate. Repullo and Suarez (2004) measured loan prices depending on internal evaluation methods within banks to calculate credit risks, and deduced fair lending rates. Loan risk influences the equilibrium loan rates directly, while indirectly bringing certain effects on loan rates through raising capital adequacy. Onorato and Altman (2005) demonstrated that there is a connection between credit risk and market risk, establishing comprehensive loan pricing model after measuring risks by simple models. Eventually, they concluded that credit spread has a positive correlation with default probability and a negative correlation with collection ratio.

Some literatures analyze the relevant factors of loan pricing in the RAROC model. Tumbull (2003) suggested that loan pricing model regards the default intensities of enterprises as a known set of data, and then establish an equation to value one unit zero-coupon bond of that business. The discount factor is the value of zero-coupon bond, discount overall future cash flows of enterprise's loans and then add it up, eventually come out a breakeven loan rate using the equation that total income is equal to total cost. Michael K. Ong (2004) built up a loan pricing device basing on the fundamental theory of RAROC, using the data sample from 1993 to 1999 to calculate repeatedly, and the empirical results conclude that risk-adjusted return is valid to price loan in some extent.

There are lots of researches on pricing of SMEs by RAROC model in recent years. Michel Dietsch and Joel Petey (2002) established minor enterprises loan portfolio risk pricing model about internal credit, using which can calculate VaR and the homologous capital used on allocating those loans. A.S. Cherry (2006) drew 'coherent risk' into RAROC model and came out a RAROC-based NGD pricing model which is an especial design for minor businesses. Jun Sheng (2000) demonstrated that RAROC pricing method does benefit coming out scientific investment decisions, and emphasized the final compensation from banking capital to risk. Consequently, regarding risk as a vital reference of demand of capital.

In recent years, with the interest rate marketization process continues to develop in China, the determination of loan interest rates for commercial banks have already had some autonomy, the studies by the RAROC model are increasing. Xuejia Lu (2007) suggested that domestic banks must perfect the loan pricing mechanisms and construct modern commercial banks' management system for the deep gap between with international frontier through improving databases, introducing experts and technologies. Feng Xue and Jin Sun found that using the current pricing methods tend to underestimate loan risk, and the compensation is inadequate to cover expected loss risk. While RAROC pricing model works out rational rates precisely and balances loan risk, which adds up flexibility and initiative in the management of banks. Zhaoyang Zhou and Haobai Wang (2012) came up the same conclusion, RAROC promotes the quality and utility of loan, however, the popularization of which requires comprehensive and detailed databases in every industry accompanied with regulations and more transparent and outward information disclosures. Yanwen Liu and Chunling Zhang (2010) demonstrated that credit rating models established under statistical analysis techniques are more likely to have stability and feasibility, and RAROC is applicable to price minor business' risky loan.

\section{Methodology}

Model. The core principle of RAROC model is that the profit must be considered on the basis of 
how much risk it takes when the bank tries to measures it. More specifically, RAROC model can be mathematically expressed as:

$$
R A R O C=\frac{(\mathrm{r} \times A-O C-D C-E L)}{E C}=\frac{(\mathrm{r} \times A-o C \times A-i \times D-E L)}{E C}
$$

In which $\mathrm{r}$ is loan interest rate, $\mathrm{A}$ is the amount of lending loan, OC is operating capital, oc is operating capital rate, DC is debt cost or capital cost, $\mathrm{i}$ is capital cost rate, EL is expected loss (risk cost) and EC is economic capital. And we also have following relevant equations:

$\mathrm{EC}=\mathrm{EAD} * \mathrm{~K}$ (coefficient of capital requirement), EL = LGD (loss given default) $*$ EDF (expected default frequency) * EAD (exposure at default) and in which oc, RAROC, LGD and EAD can be evaluated using the given data provided by supervision department, while EDF needs KMV model to work out, calculating EC and i should come out EDF first. To begin with, estimate oc, RAROC, LGD and EAD, then compute corresponding economic capital of each loan of sample firms and i, finally come out each loan's risky-based price through RAROC model.

As for economic capital, according to the IRB in the New Basel Capital Accord and under the confidence level of 99.99\%, EL $=\mathrm{K} * \mathrm{EAD}$,

$$
\mathrm{K}=\mathrm{LGD} \times\left[\Phi\left(\frac{\Phi^{-2}(P D)-\sqrt{R} \times \Phi^{-2}(0.999)}{\sqrt{1-R}}\right)-P D\right] \times\left(\frac{1+(M-25) \times \mathrm{b}}{1-1.5 \times b}\right)
$$

In which $\mathrm{R}$ is correlation coefficient, $\mathrm{M}$ is maturity and $\mathrm{b}$ is adjustment time.

Data. The data in this study are obtained from annual reports of 13 firms that have borrowed money from ICBC in 2012. Comparing the realistic loan rates with the rates worked out by RAROC loan pricing model, which empirically verifies the suitability and accuracy of using RAROC model in our country.

First, we have operating capital (153.336 billion) according to the annual report of ICBC in 2012 which is made up by operating expenses and management costs, and the total loans inside China is 7890.779 billion, then we come out the OC (1.94\%). The annual report also tells us the capital cost rate (3.85\%) that depends on cost of resource capital that year.

From commercial banks' perspective, capital is a limited resource, and the use of which requires reaching the hurdle rate. The limit of RAROC loan pricing model is correlated with the shareholders' requirements of return on capital, which is also determined by different preferences of different companies. In this paper, we use the $15 \%$ as international applied after-tax RAROC rate.

Table 1 Loan rates by the RAROC model

\begin{tabular}{c|c|c|c}
\hline & COMPANY & REAL INTEREST RATE & RISK-ADJUST INTEREST RATE \\
\hline 1 & HZHY CO. & $7.05 \%$ & $8.21 \%$ \\
\hline 2 & TG CO. & $6.55 \%$ & $6.49 \%$ \\
\hline 3 & HZHXCYCTS CO. & $6.15 \%$ & $6.10 \%$ \\
\hline 4 & ZHONHEN CO. & $7.245 \%$ & $7.36 \%$ \\
\hline 5 & ZJJSC CO. & $7.4 \%$ & $9.92 \%$ \\
\hline 6 & JLM\&E CO. & $8.32 \%$ & $10.97 \%$ \\
\hline 7 & NBD CO. & $7.05 \%$ & $7.46 \%$ \\
\hline 8 & ZJ HPL CO. & $5.76 \%$ & $5.33 \%$ \\
\hline 9 & ZJ SHD CO. & $7.04 \%$ & $9.88 \%$ \\
\hline 10 & ZJ SLES\&T LLC & $5.4 \%$ & $5.39 \%$ \\
\hline 11 & ZJ A-PM\&ECO. & $6.15 \%$ & $8.65 \%$ \\
\hline 12 & ZJ YLM CO. & $6.9 \%$ & $7.41 \%$ \\
\hline 13 & ZJ UIF CO. & $5.76 \%$ & $6.19 \%$ \\
\hline
\end{tabular}

\section{Empirical Results}

As we can see from the tables above, generally risk-adjusted loan rates are higher than the realistic 
ones, which indicates that in the pricing practices of commercial banks the credit risks of sample firms are not comprehensively taken into consideration, in other words, pricing practices using floating rates up or below the benchmark rate can't balance the loan risk and return, and let alone having a eligible measurement of unexpected loss and credit default risk.

To sum up, the loan rates provided by commercial banks yet generally underestimate the real risk level and remain inadequate compensations for existed risks. The higher default rate is, the higher risk exists. While the RAROC pricing mothed tends to come out a more eligible risk-adjusted rate and improve the quality and utility of loan transactions.

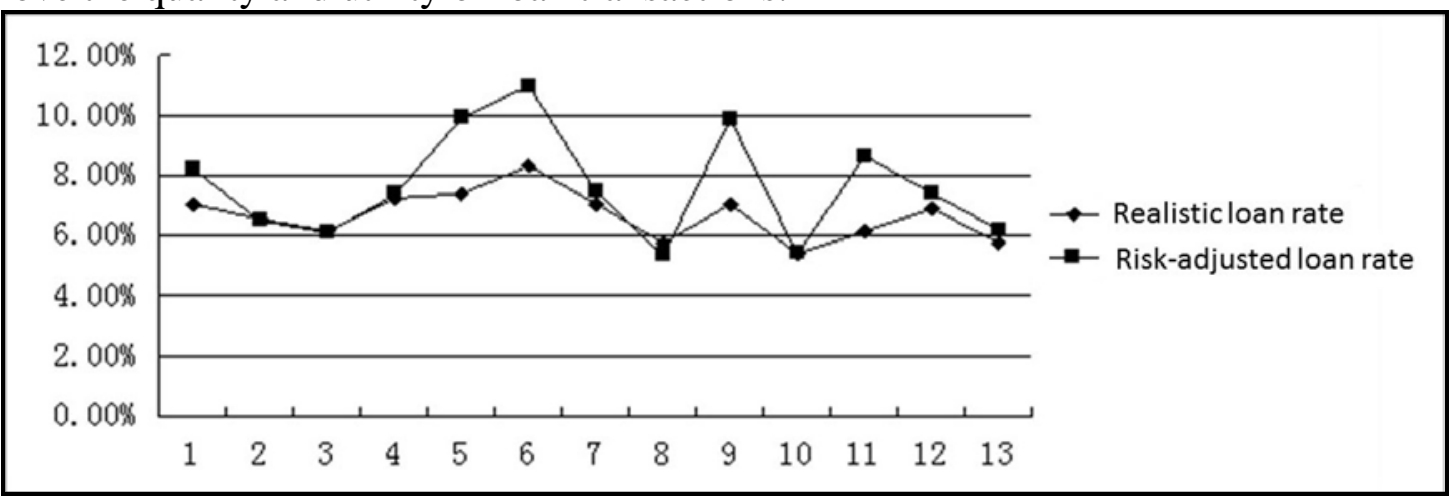

Fig. 1 The interest rate comparison between real and risk-adjusted loan rates

\section{Conclusion}

This study notices the changes in Chinese capital market, with market-oriented reforms of interest rates carried forward and deeper and more and more liberty gained by commercial banks, our analysis indicates that there are suitability and feasibility of popularizing the RAROC model in Chinese banking.

Then the empirical investigation tests the data from 13 listed minor enterprises in Zhejiang province after calculating expected loss rate and expected default frequency (EDF). The performances of risk measurement evident of the suitability and eligibility of RAROC compared with other loan pricing models. Taking risk-adjusted data into consideration and regarding expected losses as period costs, the results of RAROC loan pricing model reflect true return levels. Besides, reducing the effect brought by unexpected loss and basing on return matching risk principle, RAROC makes pricing more flexible and differential which relieves some pricing constraints across between banks and companies.

Eventually, this paper is intended to shed light on the evidence of the appliance of RAROC pricing model on commercial lending transaction is likely to enhance the risk-adjusted level and income level. RAROC is to provide a uniform measure of performance that management can use to compare the economic as opposed to the accounting profitability of business with different sources of risk and different capital requirement. RAROC model that comes out reasonable loan rates matches the interest rate liberalization in our country, thus it will become more and more popular in the future.

\section{References}

[1] Dermine, Jean. Pitfalls in the application of RAROC in loan management [J]. The Arbitageur, 1998 1(1) 21-27.

[2] Sandrine Courvoisier and Reint Gropp. Bank concentration and retail interest rates [J]. Journal of Banking \& Finance, 2002 Vol.26 2155-2189.

[3] Rafael Repullo and Javier Suarez. Venture capital finance: A security design approach [J]. Review of Finance, 2004 Vol.8 75-108. 
[4] Mario Onorato, Edward I. Altman. An integrated pricing model for default able loans and bonds [J]. European Journal of Operational Research, 2005 Vol.163 65-82.

[5] Peter S Rose. Commercial bank management [C]. McGraw-Hill, 1996.

[6] Michael K. Ong. The Basel handbook: a guide for financial practitioners [C]. University of California, 2004

[7]. ETSCH M, JOEL P. The credit risk in SME loans portfolios: modeling issues, pricing and capital requirements [J]. Journal of Banking and Finance, 200226 56-71.

[8] Michel Dietsch, Joel Petey. The credit risk in SME loans portfolios: modeling issues, pricing, capital requirements [J]. Journal of Banking Finance 200226 303-322.

[9] Turnbull, Stuart M. Pricing loans using default probabilities [J]. Economic Notes 2003 (2) 197-217.

[10] Alistair Milne, Mario Onorato. Risk-adjusted measures of value creation in financial institutions [J]. European Financial Management, 2012 578-601

[11]Thomas, George. The role and significance of funds transfer pricing in RAROC models [J]. Journal of Performance Management 200619 (3) 25-40.

[12] Lam, James C. Firmwide risk management: An integrated approach to risk management and internal control [M].In Derivative Handbook-Risk Management and Control, edited by R.J. Schwatz and J. Clifford. W. Smith. New York: John Wiley\&Sons, 2001 